\title{
Open reoperations for complications of endovascular aortic procedures: Tip of the iceberg?
}

\author{
Nicholas T. Kouchoukos, MD
}

\footnotetext{
From the Division of Cardiovascular and Thoracic Surgery, Missouri Baptist Medical Center, BJC HealthCare, St Louis, Mo.

Disclosures: Author has nothing to disclose with regard to commercial support.

Received for publication Aug 31, 2017; accepted for publication Sept 2, 2017; available ahead of print Oct 3 , 2017.

Address for reprints: Nicholas T. Kouchoukos, MD, Cardiac Thoracic and Vascular Surgery Inc, 3023 N Ballas Rd, Ste 150D, St Louis, MO 63131 (E-mail: ntkouch@aol.com).

J Thorac Cardiovasc Surg 2018;155:19-20

$0022-5223 / \$ 36.00$

Copyright (c) 2017 by The American Association for Thoracic Surgery

https://doi.org/10.1016/j.jtcvs.2017.09.004
}

In this issue, Spiliotopoulos and colleagues ${ }^{1}$ report their experience with open descending thoracic or thoracoabdominal approaches to manage complications after endovascular repair of thoracic or abdominal aortic pathology in 67 patients treated over a 19-year interval. The majority of patients $(n=45)$ underwent thoracic endovascular aortic repair (TEVAR), and the remainder $(\mathrm{n}=22)$ underwent abdominal endovascular aortic repair (EVAR). Of particular note, the frequency of procedures performed increased dramatically over this time period (see Figure $1^{1}$ ). Complications requiring intervention included aneurysm expansion (usually the result of endoleak), graft infection, fistula, aortic rupture, pseudoaneurysm, and restenosis. Forty-seven percent of patients with TEVAR had chronic dissection present at the time of that procedure, and $38 \%$ had a connective tissue disorder. All of the patients in the latter group had distal aortic dissection present at the time of reoperation.

Despite the complexity of the pathology and of the operative repairs, the early mortality rate was $4 \%$ (3 patients). All of the deaths and the majority of the postoperative complications occurred among the 45 patents who had undergone a previous TEVAR as opposed to EVAR. Despite these excellent early results, the late results were disappointing, with a number of late deaths $(n=19)$ during a median follow-up interval of 36 months. Of the 13 late deaths where the cause of death was known, 11 were aorta-related. Among the 11 patients with infection present at the time of operation, the overall mortality rate was $64 \%$ ( 7 patients). After the open procedure, 7 patients required distal aortic intervention for failure of the repair or for progression of disease. Freedom from death, repair failure, or distal aortic intervention was $49 \%$ at 5 years.

Most of the patients undergoing reoperation were referred from other centers, and the frequency of open operations after TEVAR or EVAR at the authors' center was not reported. Studies from other centers have reported rates of open reoperation after TEVAR that ranged from 3\% to $8 \%,{ }^{2-6}$ and early mortality rates of $4 \%$ to $14 \% .^{5,7,8}$ In follow-up.

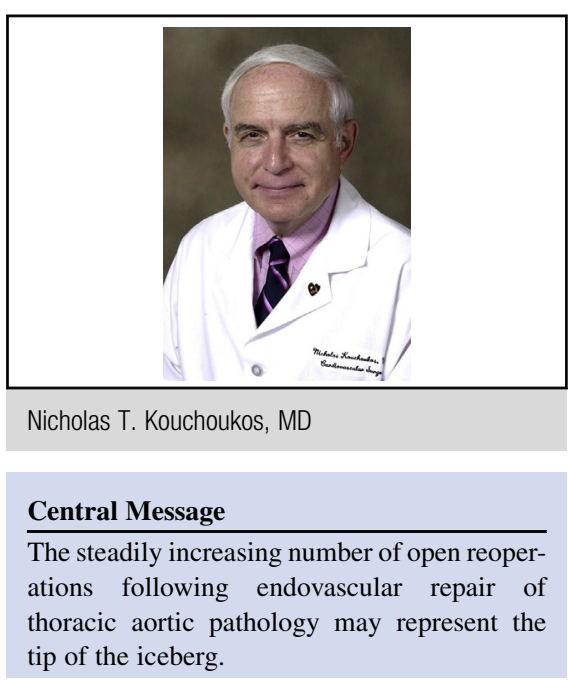

See Article page 10.

these series, endovascular interventions were also required and were performed more frequently.

What are the take home messages from this large experience? As the number of TEVAR procedures continues to increase, the frequency of open reoperations will likely increase as well; the proportion of patients who required reoperation for chronic dissection (67\%) is substantially higher than the proportion of patients undergoing TEVAR for chronic dissection noted in several large published series (in the report by Schaffer and colleagues ${ }^{9}$ of 11,966 TEVAR procedures performed between 2005 and 2010, $13.7 \%$ were performed for chronic dissection, and in a report from the Medtronic Thoracic Endovascular Registry database, chronic aortic dissection was the indication for TEVAR in 195 of 1010 patients $[19.3 \%]^{10}$ the proportion of patients with connective tissue disorders was [38\%], and all presented with dissection, a percentage also substantially higher than the percentage of patients with these conditions who receive an endograft and these 2 major disparities add to the controversies surrounding the role of TEVAR for chronic aortic dissection and for patients with connective tissue disorders); infection, particularly when associated with fistula formation, is a serious problem with high mortality; the late outcomes after open operation are not optimal; and more than one-half of the patients presented for open operation more than 1 year after TEVAR, emphasizing the need for stringent long-term 
Spiliotopoulos and colleagues ${ }^{1}$ have provided important information on the management of complications following TEVAR that require open operation. With the rapid increase in the number of TEVAR procedures performed annually, their findings may represent the tip of the iceberg.

\section{References}

1. Spiliotopoulos K, Preventza O, Green SY, Price MD, Amarasekara HS, Davis BM, et al. Open descending thoracic or thoracoabdominal aortic approaches for complications of endovascular aortic procedures: 19year experience. J Thorac Cardiovasc Surg. 2018;155:10-8.

2. Ehrlich MP, Nienaber CA, Rousseau H, Beregi JP, Piquet P, Schepens M, et al. Short-term conversion to open surgery after endovascular stent-grafting of the thoracic aorta: the Talent thoracic registry. J Thorac Cardiovasc Surg. 2008; 135:1322-6.

3. Geisbüsch P, Hoffmann S, Kotelis D, Able T, Hyhlik-Dürr A, Böckler D. Reinterventions during midterm follow-up after endovascular treatment of thoracic aortic disease. J Vasc Surg. 2011;53:1528-33.
4. Szeto WY, Desai ND, Moeller P, Moser GW, Woo EY, Fairman RM, et al. Reintervention for endograft failures after thoracic endovascular aortic repair. $J$ Thorac Cardiovasc Surg. 2013;145:S165-70.

5. Canaud L, Alric P, Gandet T, Ozdemir BA, Albat B, Marty-Ane C. Open surgical secondary procedures after thoracic endovascular repair. Eur J Vasc Endovasc Surg. 2013;46:667-74.

6. Scali ST, Beck AW, Butler K, Feezor RJ, Martin TD, Hess PJ, et al. Pathology specific secondary aortic interventions after thoracic endovascular aortic repair. J Vasc Surg. 2014;59:599-607.

7. Nozdrzykowski M, Luehr M, Garbade J, Schmidt A, Leontyev S, Misfeld M, et al. Outcomes of secondary procedures after primary thoracic endovascular aortic repair. Eur J Cardiothoracic Surg. 2016;49:770-7.

8. Roselli EE, Abdel-Halim M, Johnston DR, Soltesz EG, Greenberg RK, Svensson LG, et al. Open aortic repair after prior thoracic endovascular aortic repair. Ann Thorac Surg. 2014;97:750-6.

9. Schaffer JM, Lingala B, Miller DC, Woo JW, Mitchell RS, Dake MD. Midterm survival after thoracic endovascular aortic repair in more than 10,000 Medicare patients. J Thorac Cardiovasc Surg. 2015;149:803-23.

10. Patterson B, Holt P, Nienaber C, Cambria R, Fairman R, Thompson M. Aortic pathology determines midterm outcome after endovascular repair of the thoracic aorta: report from the Medtronic Thoracic Endovascular Registry (MOTHER) database. Circulation. 2013;127:24-32. 